\title{
The activity and kinetic parameters of oxidoreductases in phaeozem in response to long-term fertiliser management
}

\author{
Z.C Shang ${ }^{1,2,4}$, L.L Zhang ${ }^{1 *}$, Z.J. Wu ${ }^{1}$, P. Gong ${ }^{1,4}$, D.P. Li ${ }^{1}$, P. Zhu ${ }^{3}$ and H.J. Gao ${ }^{3}$ \\ ${ }^{1}$ Instituite of Applied Ecology, Chinese Academy of Sciences, P. O. Box 417, Shenyang, 110016, China. \\ ${ }^{2}$ Shanghai Research Institute of Chemical Industry, Shanghai, 200062, China. ${ }^{3}$ Research Center of Agricultural \\ Environment and Resources, Jilin Academy of Agricultural sciences, P. O. Box 306. Changchun, 130124, \\ China. ${ }^{4}$ Graduate School of the Chinese Academy of Sciences, Beijing 100039, China. ${ }^{*}$ Corresponding author: \\ zhanglilisy@yahoo.com.cn
}

\begin{abstract}
This study describes the effects of balanced versus nutrient-deficient fertilisation on soil nutrient content and selected oxidoreductase activity and kinetic parameters in a long-term (28 years) field experiment conducted using a phaeozem type soil in the Jilin Province of northeast China. As compared to no or unbalanced fertilisation, balanced fertilisation improved the overall chemical fertility of the soil and significantly increased the activities and Vmax values of soil dehydrogenase and catalase. Compared with control (CK), unbalanced fertilisation (with the exception of $\mathrm{P}$ deficiency) significantly increased the total carbon content and soil dehydrogenase activity but had less of an effect on the Vmax of the enzyme, whereas the soil catalase activity and its Vmax were less affected under unbalanced fertilisation conditions. The $K m$ value of soil dehydrogenase increased with the application of chemical NPK combined with farmyard manure but decreased under the application of NPK, NP, and PK. The Km value of soil catalase decreased under the application of NK and showed little difference between CK and the other fertilisation treatments. The variations in the activities and kinetic parameters of the enzymes revealed the benefits of long-term balanced fertilisation, particularly the combined application of chemical and organic fertilisers, by improving the chemical and biological fertility of phaeozem. The results also indicated that unbalanced fertilisation with P deficiency (NK) could enhance phaeozem quality, but this effect was limited.
\end{abstract}

Keywords: Enzymatic kinetic parameters, dehydrogenase, catalase, phaeozem, fertilisation. 


\section{Introduction}

The dehydrogenase and catalase activities in soil are mainly associated with soil microbes (García-Gil et al., 2000; Masciandaro et al., 2000; Zhang et al., 2009). In general, the activities of these enzymes can be used to characterise the abundance and metabolic activity of soil microbes, whereas their kinetic parameters are used to describe the catalytic activity, origin, and substrate affinity of the enzymes (García-Gil et al., 2000; Zhang et al., 2009). Many studies have examined the effects of different fertilisation systems on the activities of these enzymes, but little information is available concerning the long-term effects of fertiliser management on the activities and kinetic parameters of these two enzymes (Chu et al., 2007, Borowska and Koper, 2010).

Organic and inorganic fertilisers are primarily used to increase the availability of nutrients; however, organic fertilisers usually increase the physical and chemical characteristics of the soil and enzymatic activity (Masto et al., 2006, Chu et al., 2007, Borowska and Koper, 2010). It has been reported that inorganic fertilisers have a relatively reduced effect on the soil microbial activity than organic fertilisers (Hopkins and Shiel, 1996). Masciandaro et al., (2000) found that the Vmax value of soil dehydrogenase markedly increased under organic (manure) versus chemical fertiliser (urea) but that its $\mathrm{Km}$ value did not change, indicating that the use of organic fertiliser caused an increase of dehydrogenase in the active microbial biomass but did not alter its substrate affinity. GarcíaGil (2000) indicated that the catalase activity was increased in soil treated with organic fertiliser due to the stimulation of enzyme biosynthesis by the addition of organic residues (García-Gil et al., 2000).

The balanced supplementation of major nutrient elements $(\mathrm{N}, \mathrm{P}, \mathrm{K})$ is usually beneficial for plant growth. However, in China, farmers are often forced to make economical decisions about their fertiliser management strategies rather than from the viewpoint of sustainable development (Chu et al., 2007). When the farmer is under economic stress, the nitrogen and, to a lesser extent, phosphorus levels are usually maintained, but the need for potassium is either underestimated or ignored. As a result, unbalanced fertilisation remains widespread. It is, therefore, urgent to formulate a rational fertilisation system that can both maintain the farmers' income and improve the quality of the soil.

Phaeozem is an agricultural soil found in approximately $20.2 \%$ of all arable land (Wang et al., 2009) and is the prevalent soil type in the Jilin Province of northeast China, an important grain production area of the country. To assist the local farmers in developing a rational fertilisation strategy, a long-term field experiment with maize was conducted in Gongzhuling City. Many studies have revealed that long-term fertilisation, whether balanced or unbalanced, influences both the abundance and composition of the soil microbial community (Wu et al., 2011; Wertz et al., 2012). Because the enzymes in the soil originate mainly from these microorganisms, our hypothesis was that balanced or unbalanced long-term fertilisation could alter the specific activity and kinetic parameters of oxidoreductases to differing degrees. The aim of this study was to evaluate the changes in the activities and kinetic characteristics of selected oxidoreductase under different long-term fertiliser managements.

\section{Materials and methods}

\subsection{Site description and field experiment}

The long-term experimental site in Gongzhuling City

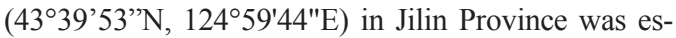
tablished in 1979. The mean annual temperature is 
$5-6^{\circ} \mathrm{C}$, with maximum and minimum temperatures of $36.6^{\circ} \mathrm{C}$ and $-34.6^{\circ} \mathrm{C}$, respectively. This area experiences four distinct seasons, with a cold winter and a warm summer (June-August). The area has an annual precipitation of approximately $570 \mathrm{~mm}$, with $70 \%$ of the total rain falling in June, July, and August. The nonfrost period lasts for 120-140 days. Six treatment types were tested: Control (no fertilisation, CK), NK, NP, PK, NPK, and M+NPK (farmyard manure plus NPK). Each treatment comprised an area of $100 \mathrm{~m}^{2}$ and was performed in three replicates. The annual amounts of chemical fertilisers and farmyard manure used were $165 \mathrm{~kg} \mathrm{hm}^{-2} \mathrm{~N}, 82.5 \mathrm{~kg} \mathrm{hm}^{-2} \mathrm{P}_{2} \mathrm{O}_{5}, 82.5 \mathrm{~kg} \mathrm{hm}^{-2} \mathrm{~K}_{2} \mathrm{O}$, and $23100 \mathrm{~kg} \mathrm{hm}^{-2}$ manure. The M+NPK regimen involved the application of the same $\mathrm{N}$ amount as the other N-containing treatments and included $49.5 \mathrm{~kg}$ $\mathrm{hm}^{-2}$ inorganic $\mathrm{N}$ and $115.5 \mathrm{~kg} \mathrm{hm}^{-2}$ organic $\mathrm{N}$. All of the fertilisers were applied as base fertiliser.

\subsection{Soil sampling}

A total of five soil cores $\left(60 \mathrm{~cm}^{3}\right)$ were collected from each treatment replicate after harvesting the maize and were pooled into a composite sample. A portion of the sample was air-dried and sieved through a $2 \mathrm{~mm}$ mesh for the analysis of the chemical properties; another portion was kept fresh and sieved $(2 \mathrm{~mm}$ ) for the measurements of the enzyme activity and kinetic parameters.

\subsection{Assays of the soil chemical properties}

The total $\mathrm{C}$ and $\mathrm{N}$ contents were determined using an element analyser (Elementar Vario EL) (Matejovic, 1995), and the total P content was determined using the $\mathrm{HClO}_{4}$ digestion method (Olson and Sommers, 1982). The available $\mathrm{N}$ content was extracted from fresh subsamples with $2 \mathrm{M} \mathrm{KCl}$ and measured using a continuous flow analyser (AAШ German). The available $\mathrm{P}$ content was determined by extraction with 0.5
$\mathrm{M} \mathrm{NaHCO}_{3}$ and was measured colorimetrically using molybdate (Olsen and Sommers, 1982). The available $\mathrm{K}$ content was determined by extraction with ammonium acetate and was measured using flame photometry (Shi, 1976). The soil $\mathrm{pH}$ was determined using a glass electrode (LICI, PHS-3C).

\subsection{Measurements of the soil enzyme activities}

The soil dehydrogenase activity (mg TPF per g soil per $24 \mathrm{~h}$ ) was determined by the spectrophotometric measurement of 2,3,5-triphenylformazan (TPF) formation after the soil samples were treated with 2,3,5-triphenyltetrazolium chloride (TTC) at $37{ }^{\circ} \mathrm{C}$ for $24 \mathrm{~h}$ (Tabatabai, 1994). The soil catalase activity ( $m m o l \mathrm{H}_{2} \mathrm{O}_{2}$ per $\mathrm{g}$ soil per $\mathrm{h}$ ) was determined by the colorimetric measurement of unreacted $\mathrm{H}_{2} \mathrm{O}_{2}$ after the soil samples were treated with $\mathrm{H}_{2} \mathrm{O}_{2}$ at $20^{\circ} \mathrm{C}$ for 10 min (Trasar-Cepeda et al., 1999).

\subsection{Measurements of the soil enzyme kinetic parameters}

The substrate concentrations for the measurement of the soil dehydrogenase and catalase activities ranged from 10 to $90 \mathrm{mM}$ and from 2 to $16 \mathrm{mM}$, respectively (the series of substrate concentrations are 10, 20, $30,50,70$, or $90 \mathrm{mM}$ and $2,4,6,10,13$, or $16 \mathrm{mM}$, respectively). The kinetic parameters $\operatorname{Vmax}$ and $\mathrm{Km}$ were determined using the Lineweaver-Burk version of the Michaelis-Menten equation, as follows:

$$
\frac{1}{V}=\frac{k m}{V \max } \cdot \frac{1}{[S]}+\frac{1}{V \max }
$$

where $V$ is the reaction velocity, Vmax is the maximum reaction velocity, $\mathrm{Km}$ is the Michaelis constant (the substrate concentration at half-maximal reaction velocity) and $[\mathrm{S}]$ is the substrate concentration. 


\subsection{Statistical analysis}

The statistical analysis was performed using Microsoft Excel 2000 and the SPSS 16.0 program for Windows. All of the data shown in the tables and figures represent the mean \pm SD of three replicates. A $P$ value less than 0.05 was considered statistically significant. The soil data were calculated based on the oven-dried $\left(105^{\circ} \mathrm{C}\right)$ weight. Multiple comparisons (Student-NewmanKeuls) were analysed using one-way ANOVA tests, and the correlation of the soil parameters was based on Pearson correlation coefficients. The IFI (Integrated Fertility Index) was calculated according to the following equation:

$$
I F I=\sum_{i=1}^{n} W i x N i
$$

where $W i$ and $N i$ are the weight coefficient and mean membership value, respectively (Jiang et al., 2002).

\section{Results}

\subsection{Soil nutrient contents and $\mathrm{pH}$ value}

Compared with CK, all of the fertilisation treatments, with the exception of NK, had significantly higher amounts of total $\mathrm{C}, \mathrm{N}$, and $\mathrm{P}$, and the balanced fertilisation (NPK and M+NPK) was superior in elemental content to the unbalanced fertilisation (NP and PK) $(p<0.05)$. The mineral $\mathrm{N}$ content was significantly higher under the fertilisation treatments containing $\mathrm{N}$, and this content was also significantly higher under the balanced fertilisation protocols. The available $\mathrm{P}$ content was significantly higher under the balanced fertilisation conditions, with the highest amount found for M+NPK. Under the balanced fertilisation conditions, the soil $\mathrm{pH}$ was also significantly lower in comparison with the unbalanced fertilisation and control conditions (Table 1).

Table 1. Soil nutrient contents and $\mathrm{pH}$ values.

\begin{tabular}{lcccccc}
\hline Treatment & Total C & Total N & Total P & Mineral N & Available P & pH \\
\hline & & $\mathbf{g ~ k g}^{-1}$ & & \multicolumn{2}{c}{$\mathbf{m g ~ k g}^{-1}$} & $\mathbf{1 : 2 . 5}$ \\
\hline CK & $31.07 \pm 2.34 \mathrm{~d}$ & $1.47 \pm 0.02 \mathrm{c}$ & $0.64 \pm 0.02 \mathrm{c}$ & $13.45 \pm 1.23 \mathrm{c}$ & $38.41 \pm 2.68 \mathrm{c}$ & $7.66 \pm 0.98 \mathrm{a}$ \\
NK & $32.57 \pm 3.54 \mathrm{~d}$ & $1.54 \pm 0.04 \mathrm{c}$ & $0.69 \pm 0.04 \mathrm{c}$ & $18.23 \pm 1.76 \mathrm{~b}$ & $40.25 \pm 3.84 \mathrm{c}$ & $7.54 \pm 1.54 \mathrm{a}$ \\
NP & $37.14 \pm 2.87 \mathrm{c}$ & $2.17 \pm 0.01 \mathrm{~b}$ & $0.97 \pm 0.03 \mathrm{~b}$ & $19.53 \pm 2.56 \mathrm{~b}$ & $51.54 \pm 3.97 \mathrm{c}$ & $7.38 \pm 1.26 \mathrm{a}$ \\
PK & $39.41 \pm 4.58 \mathrm{c}$ & $2.05 \pm 0.03 \mathrm{~b}$ & $1.12 \pm 0.05 \mathrm{~b}$ & $13.85 \pm 2.64 \mathrm{c}$ & $50.98 \pm 5.87 \mathrm{c}$ & $7.73 \pm 0.27 \mathrm{a}$ \\
NPK & $45.18 \pm 4.87 \mathrm{~b}$ & $2.88 \pm 0.02 \mathrm{a}$ & $2.69 \pm 0.14 \mathrm{a}$ & $28.76 \pm 4.87 \mathrm{a}$ & $89.04 \pm 5.98 \mathrm{~b}$ & $7.18 \pm 0.95 \mathrm{~b}$ \\
M+NPK & $53.66 \pm 4.21 \mathrm{a}$ & $2.94 \pm 0.01 \mathrm{a}$ & $2.47 \pm 0.28 \mathrm{a}$ & $31.87 \pm 2.76 \mathrm{a}$ & $124.80 \pm 17.54 \mathrm{a}$ & $7.20 \pm 0.64 \mathrm{~b}$ \\
\hline
\end{tabular}

Data not followed by the same letters in a column represent a significant difference $(p<0.05)$.

\subsection{Soil dehydrogenase activity and kinetic parameters}

All of the fertilisation conditions, except for NK, demonstrated significant increases in the soil dehy- drogenase activity, with the highest increase found with M+NPK and smaller differences for the other conditions (Figure 1a). The dehydrogenase Vmax value was also the highest for M+NPK $(p<0.05)$ and showed smaller changes for the other conditions 
(Figure 1b). Furthermore, the $K m$ value was the highest under the M+NPK treatment $(p<0.05)$ and was significantly lower for NP, PK, and NPK than for CK and NK (Figure 1c).
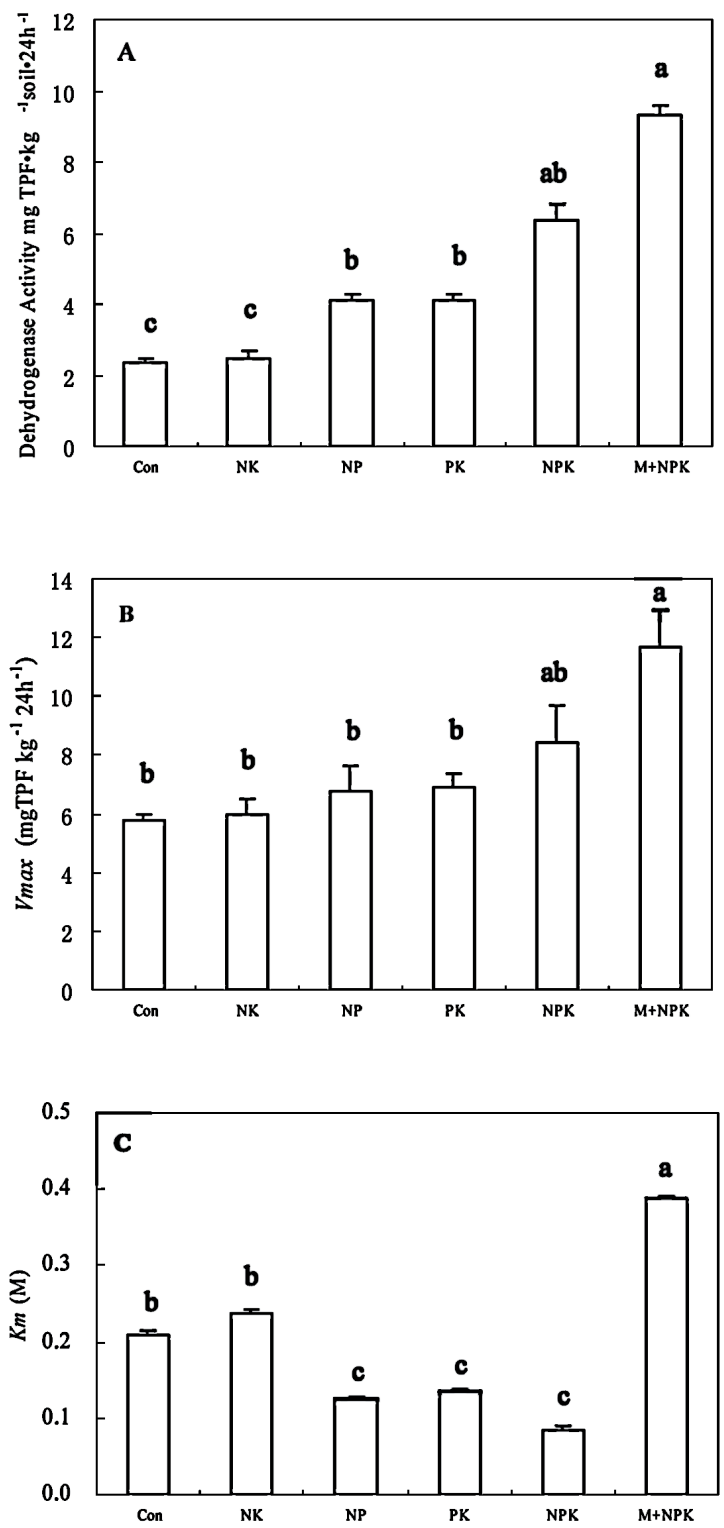

Figure 1. Soil dehydrogenase activity and kinetic parameters. (A) Activity, (B) Vmax, and (C) Km. The vertical bars are the S.D.S. The different letters above the histograms represent significant differences $(p<0.05)$. 


\subsection{Soil catalase activity and kinetic parameters}

The soil catalase activity was significantly higher under the M+NPK treatment and lower for NK than the other conditions (Figure 2a). The Vmax and $\mathrm{Km}$ values were significantly higher for M+NPK and NK, respectively, compared to the other treatments (Figure $2 \mathrm{~b}$ and Figure 2c).
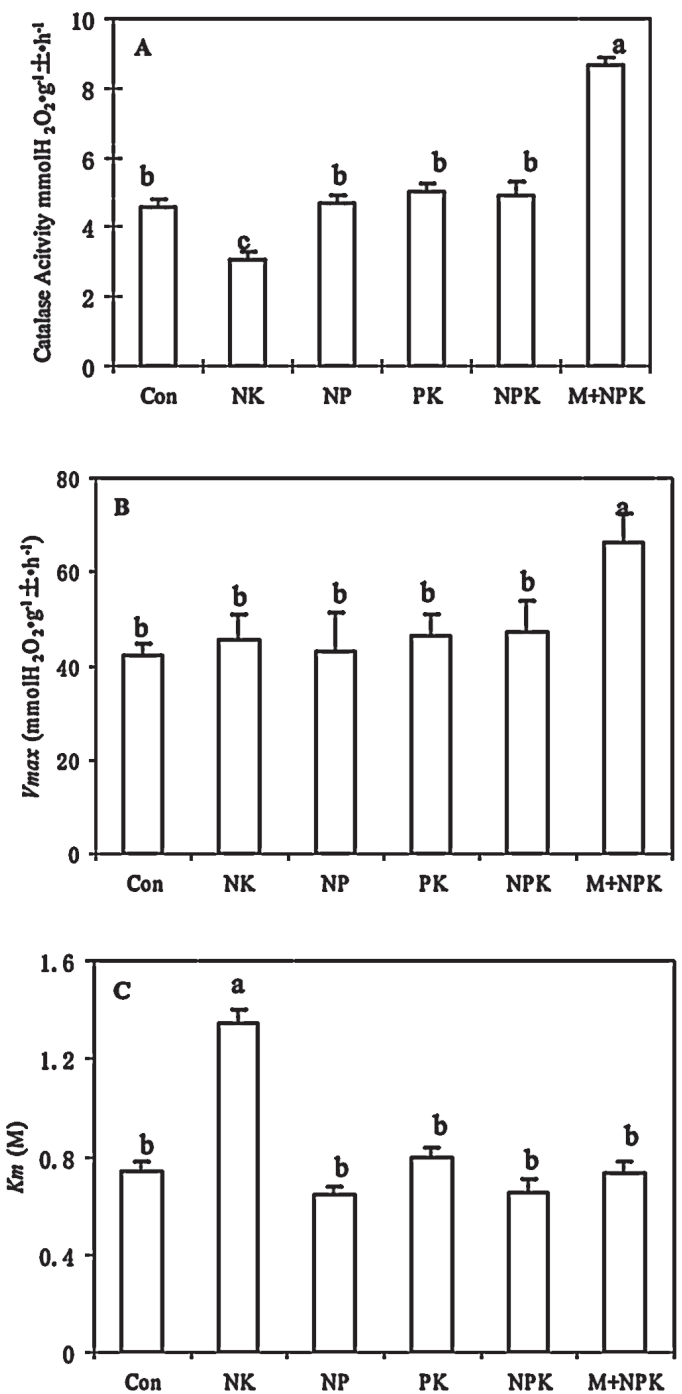

Figure 2. Soil catalase activity and kinetic parameters. (A) Activity, (B) Vmax, and (C) Km. The vertical bars are the S.D.S. The different letters above the histograms represent significant differences $(p<0.05)$. 
3.4 Correlations between the soil chemical properties and enzyme kinetic parameters

The soil dehydrogenase activity and its Vmax value were positively correlated with the chemical properties of the soil (except for the $\mathrm{pH}$ ), whereas its $\mathrm{Km}$ value had no correlation with any of the tested chemical properties (Table 2). Similarly, the soil catalase activity and its $\operatorname{Vmax}$ value were also positively correlated with the total $\mathrm{C}$ content, and its $\mathrm{Km}$ value had no significant correlation with any of the tested chemical properties (Table 3).

Table 2. Correlations between the soil chemical properties and soil dehydrogenase activities.

\begin{tabular}{lccccccc}
\hline & Organic C & Total N & Mineral N & $\mathbf{p H}$ & $\begin{array}{c}\text { Dehydrogenase } \\
\text { activity }\end{array}$ & Vmax & Km \\
\hline Organic C & 1 & & & & & \\
Total N & $0.944^{* *}$ & 1 & & & & \\
Total P & $0.904^{*}$ & $0.956^{* *}$ & & & & \\
Mineral N & $0.877^{*}$ & $0.895^{*}$ & 1 & & & \\
Available P & $0.976^{* *}$ & $0.916^{*}$ & $0.932^{* *}$ & & & \\
pH & -0.745 & -0.845 & -0.954 & 1 & & \\
Dehydrogenase & $0.994^{* *}$ & $0.935^{* *}$ & $0.900^{*}$ & -0.780 & 1 & \\
activity & $0.977^{* *}$ & $0.877^{*}$ & $0.884^{*}$ & -0.742 & $0.990^{* *}$ & 1 \\
Vmax & 0.399 & 0.114 & 0.365 & -0.183 & 0.451 & 0.572 & 1 \\
Km & & & & & & \\
\hline
\end{tabular}

${ }^{* *}$ Correlation is significant at the 0.01 level (2-tailed test).

*Correlation is significant at the 0.05 level (2-tailed test).

Table 3. Correlations between the soil chemical properties and soil catalase activities.

\begin{tabular}{lccccccc}
\hline & Organic C & Total N & Mineral N & pH & $\begin{array}{c}\text { Catalase } \\
\text { activity }\end{array}$ & Vmax & Km \\
\hline Organic C & 1 & & & & & \\
Total N & $0.944^{* *}$ & 1 & & & & \\
Total P & $0.904^{*}$ & $0.956^{* *}$ & & & & \\
Mineral N & $0.877^{*}$ & $0.895^{*}$ & 1 & & & \\
Available P & $0.976^{* *}$ & $0.916^{*}$ & $0.932^{* *}$ & & & \\
pH & -0.745 & -0.845 & -0.954 & 1 & & \\
Catalase activity & $0.875^{*}$ & 0.724 & 0.671 & -0.519 & 1 & \\
Vmax & $0.876^{*}$ & 0.683 & 0.764 & -0.570 & $0.907^{*}$ & 1 \\
Km & -0.426 & -0.550 & -0.265 & 0.338 & -0.497 & -0.119 & 1 \\
\hline
\end{tabular}

${ }^{* *}$ Correlation is significant at the 0.01 level (2-tailed test).

*Correlation is significant at the 0.05 level (2-tailed). 
3.5 Soil chemical integrated fertility index (SCIFI) and soil biological integrated fertility index (SBIFI)

The SCIFI and SBIFI reflect the results of the soil integrated fertility level. The highest values were found for M+NPK, indicating the highest integrated fertility due to the combined application of organic matter and NPK. There was a significant correlation between the SCIFI and SBIFI $(p<0.05)$, showing that fertiliser application has a similar effect on both the chemical and biological fertility (Table 4).

Table 4. SCIFI, SBIFI and their correlation.

\begin{tabular}{lcc}
\hline Treatment & SCIFI & SBIFI \\
\hline CK & 28.61 & 14.25 \\
N1K & 30.03 & 14.14 \\
N1P & 34.27 & 14.52 \\
PK & 36.28 & 15.60 \\
N1PK & 41.82 & 15.78 \\
M+N2PK & 49.62 & 23.30 \\
\hline
\end{tabular}

Correlation between SCIFI and SBIFI

$0.894(p<0.05)$

SCIFI: Soil Chemical Integrated Fertiliser Index; SBIFI: Soil Biological Integrated Fertiliser Index.

\section{Discussion}

In this study, fertilisation was shown to benefit the accumulation of the total $\mathrm{C}, \mathrm{N}$, and $\mathrm{P}$ contents. The balanced fertilisation, particularly chemical NPK plus farmyard manure, improved the overall chemical fertility of the soil, which is consistent with the results of other studies (Li et al., 2007). The significantly higher mineral $\mathrm{N}$ content under the fertilisation treatments containing $\mathrm{N}$ could be due to more $\mathrm{N}$ being immobilised and released by soil microbes, whereas the significantly higher available $\mathrm{P}$ content under the balanced fertilisation treatment suggested that this type of treatment improved the immobilisation and turnover of microbial P. Although the soil $\mathrm{pH}$ under the balanced fertilisation was significantly lower than the other treatments, it was still not very acidic, suggesting that long-term fertilisation had little impact on the soil $\mathrm{pH}$.

Soil dehydrogenase and catalase, intracellular enzymes found in anaerobic and aerobic microorganisms, are often used as indicators of the overall microbial activity in the soil (Masciandaro et al., 2000). Their increased activities under the M+NPK treatment were consistent with the studies conducted by Franco-Otero (2012), Guo (2011) and Borowska (2010). Flanagan and Vancleve (1983) suggested that the microbial activity was limited more by the availability of $\mathrm{C}$ than by nutrient availability, which explains the results of the M+NPK treatment because of the C supplied by the manure (Linn and Doran, 1984; Bergstorm et al., 1998).

The correlation analysis also indicated that the activities of the two enzymes were positively correlated with the total $\mathrm{C}$ and $\mathrm{N}$ contents, findings that are consistent with the results of Franco-Otero et al., (2012).

Whereas the activity of a certain enzyme only provides an indication of its amount in the sample and its contribution to the turnover of a specific substrate (Farrell et al., 1994), its kinetic parameters can provide useful information regarding the characteristics (e.g., stability and substrate affinity) of the enzyme under specific soil conditions (Perez-Mateos and Gonzales Carcedo, 1985).

In this study, the Vmax values of soil dehydrogenase and catalase under the M+NPK treatment were significantly higher, suggesting that the two enzymes had modified catalytic activities and significant higher production levels in the active soil microbial biomass 
under the combined application of chemical and organic fertilisers. Masciandaro et al., (2000) also found a marked increase of the soil dehydrogenase Vmax value under combined chemical and organic fertilisation. As the soil enzymes catalysing the same biochemical reactions can have different origins and, thus, different $K m$ values (Nannipieri et al., 2002), the different $\mathrm{Km}$ values of soil dehydrogenase under the different fertilisation treatments suggested that the fertilisation altered the origin of the enzyme. In contrast, the $\mathrm{Km}$ values of soil catalase showed little difference (except for NK), suggesting that fertilisation had less of an effect on the origin of this enzyme.

The substrate affinity of these enzymes has been shown to improve after organic fertilisation (Tabatabai, 1994), but the $K m$ value of soil dehydrogenase increased significantly for M+NPK. The only possible reason for this could be that the increase in the amount of exogenous dehydrogenase from the farmyard manure was higher than the decrease of the substrate affinity of the endogenous dehydrogenase.

The average maize grain yields of the experiment from 1979 to 2007 were ranked as follows: M+NPK, NPK $>$ NP $>$ PK $>$ NK > CK (Peng et al., 2010). Previous studies revealed that the grain yield and nitrogen usage efficiency was significantly related to enzyme activities. In the present study, the balanced fertilisation increased the Vmax value of soil dehydrogenase, a finding that is consistent with reported results (Colla et al., 2011; Sun et al., 2012). Based on the IFI values, the combination of organic and inorganic fertilisation is the best method to improve soil fertility. The results obtained in this study revealed the importance of long-term balanced fertilisation on the chemical and biological soil fertility and the maize yield. In particular, the combined application of chemical and organic fertilisers increased these valuable characteristics in phaeozem soil.

\section{Conclusions}

The chemical and biological fertility of phaeozem was significantly improved by long-term balanced fertilisation, especially under the combined application of chemical and organic fertilisers. The strong increase in the Vmax of the enzymes under the M+NPK treatment indicated an increase in the amount of the enzymes. Our research also indicated that unbalanced fertilisation under P deficiency (NK) had a limited effect on enhancing the quality of phaeozem soil.

\section{Acknowledgments}

Support from the National Natural Science Foundation of China (41101242) and the National Science \& Technology Pillar Program (2011BAD11B04, 2012BAD14B02) is gratefully acknowledged. We also thank Likai Zhou, Professor of the Institute of Applied Ecology, for revising this manuscript.

\section{References}

Bergstorm, D.W., Monreal, C.M., Millette, J.A. 1998. Spatial dependence of soil enzyme activities along a slope. Soil Science Society of America Journal. 62,1302-1308.

Borowska, K., Koper, J. 2010. The effect of long-term organic-mineral fertilisation on selenium content and chosen oxidoreductases activity under winter wheat cultivation. Chemistry and Ecology. 26, 111-116.

Chu, H.Y., Lin, X.G., Fujii, T., Morimoto, S., Yagi, K., Hu, J., Zhang, J.B. 2007. Soil microbial biomass, dehydrogenase activity, bacterial community structure in response to long-term fertilizer management. Soil Biology and Biochemistry. 39, 2971-2976. 
Colla, G., Rouphael, Y., Mirabelli, C., Cardarelli, M. 2011. Nitrogen-use efficiency traits of mini-watermelon in response to grafting and nitrogen-fertilization doses. Journal of Plant Nutrition and Soil Science. 174, 6-10.

Farrell, R.E., Gupta, V.V.S.R., Germida, J.J. 1994. Effects of cultivation on the activity and kinetics of arylsulfatase in Saskatchewan soils. Soil Biology and Biochemistry. 26, 1033-1040.

Flanagan, P.W., Vancleve, K. 1993. Nutrient cycling in relation to decomposition and organic-matter quality in taiga ecosystems. Can. J. Forest Res. $13,795-817$.

Franco-Otero, V.G., Soler-Rovira, P., Hernández, D., López-de-Sá, E.G., Plaza, César. 2012. Shortterm effects of organic municipal wastes on wheat yield, microbial biomass, microbial activity, and chemical properties of soil. Biology and Fertility of Soil. 48, 205-216.

García-Gil., Plaza, C., Soler-Rovira, P., Polo, A. 2000. Long-term effects of municipal solid waste compost application on soil enzyme activities and microbial biomass. Soil Biology and Biochemistry. 32, 1907-1913.

Guo, P., Wang, C.Y., Jia, Y., Wang, Q., Han, G.M., Tian, X.J. 2011. Response of soil microbial biomass and enzymatic activities to fertilizations of mixed inorganic and organic nitrogen at a subtropical forest in East China. Plant and Soil. 338, 355-366.

Hopkins, D.W., Shiel, R.S. 1996. Size and activity of soil microbial communities in long-term experimental grassland plots treated with manure and inorganic fertilizers. Biology and Fertility of Soils. 22,66-70.

Jiang, C.Q., Xu, Q., Jiang, P.K. 2002. Integrated evaluation of soil chemical and biochemical fertility under differnet vegetations. Forest Research. $15,700-705$
Li, L.Q., Zhang, X.H., Zhang, P.J. 2007. Variation of organic carbon and nitrogen in aggregate size fractions of a paddy soil under fertilisation practices from Tai Lake Region, China. Journal of the Science of Food and Agriculture. 87, 1052-1058.

Linn, D.M., Doran, J.W. 1984. Aerobic and anaerobic microbial-populations in no-till and plowed soils. Soil Science Society of America Journal. 48, 794-799.

Masciandaro,G., Ceccanti,B., Ronchi,V., Bauer,C. 2000. Kinetic parameters of dehydrogenase in the assessment of the response of soil to vermicompost and inorganic fertilizers. Biology and Fertility of Soils. 32, 479-483.

Masto, R.E., Chhonkar, P.K., Singh, D., Patra, A.K. 2006a. Changes in soil biological and biochemical characteristics in a long-term field trial on a sub-trophical inceptisol. Soil Biology and Biochemistry. 38,1577-1582.

Matejovic,I. 1995. Total nitrogen in plant-material determination by means of dry combustion-a possible alternative to determination by kjeldahl digestion. Communications in Soil Science and Plant Analysis. 26, 2217-2229.

Nannipieri,P.B., Kandler,E., Ruggiero,P. 2002. Enzyme Activity and Microbial and Biochemical Processes in Soil. In: R.G. Burns, R.P. Dick (Eds.). Enzymes in the Environment: Activity, Ecology and Applications. Marcel Dekker Inc, New York, pp. 1-33.

Olson, S.R., Sommers, L.E. 1982. Phosphorus. In: Page et al., Editors (2nd ed.), Methods of soil analysis, part 2 vol 9, American Society of Agronomy, Soil Science Society of America, Madison, Wisconsin USA, pp. 403-430.

Peng, C., Gao, H.J., Li, Q., Zhu, P., Zhang, X.P. 2010. Dynamic Changes of Soil Water Content in Longterm Continuous Cropping and Rotation Cropping Systems. Jilin Agricultural Sciences. 35,26-28. 
Perez-Mateos, M., Gonzales-Carcedo, S. 1985. Effect of fractionation on the enzymatic state and behavior of enzyme activities in different structural soil units. Biology and Fertility of Soils. 1, 153-159.

Shi, R. 1976. Soil and Agricultural Chemistry Analysis. China Agricultural Press, Beijing, pp 388 (in Chinese).

Sun, Y.J., Ma, J., Sun, Y.Y. 2012. The effects of different water and nitrogen managements on yield and nitrogen use efficiency in hybrid rice of China. Field Crops Research. 127,85-98

Tabatabai M.A. 1994. Soil Enzymes. In: R.W. Weaver et al., (Eds.) Methods of Soil Analysis: Microbiological and Biochemical Properties. Part 2.SSSA Book Ser. 5. Soil Science Society of American, Madison, pp. 775-833.

Trasar-Cepeda C., Camina, F., Leiros, M.C., GilStotres, F. 1999. An improved method to measure catalase activity in soils. Soil Biology and Biochemistry. 31, 483-485.
Wertz, S., Leigh, A.K.K., Grayston, S.J. 2012. Effects of long-term fertilization of forest soils on potential nitrification and on the abundance and community structure of ammonia oxidizers and nitrite oxidizers. FEMS Microbiology Ecology. $79,1,142-154$.

Wu, M.N., Qin, H.L., Chen, Z. 2011. Effect of longterm fertilization on bacterial composition in rice paddy soil. Biology and Fertility of Soils. 47,4, 397-405.

Wang, J.K., Wu, Y., Su, Q.R. 2009 General situation of northeast black soil. In: Han G.Q., Yang L.Z. (eds): Present land use and development strategy of Northeast black soil resources. China: Chinese Land Publishing House, 1-15.

Zhang, L.L., Wu, Z.J., Chen, L.J., Jiang, Y., Li, D.P. 2009. Kinetics of catalase and dehydrogenase in main soils of Northeast China under different soil moisture conditions. Agricultural Journal. 4, 113-120. 
